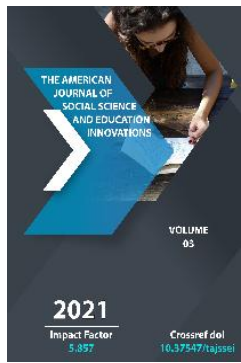

\title{
The Effectiveness Of Transformational Trends In The Use Of Pedagogical Technologies In The Formation Of National Musical Hearing Skills Among Students
}

Elmurod Tadjibayev

Doctoral Student, Namangan State University, Namangan, Uzbekistan

Journal Website:

http://theamericanjour

nals.com/index.php/taj

ssei

Copyright: Original content from this work may be used under the terms of the creative commons attributes 4.0 licence.

\section{ABSTRACT}

This article examines the effectiveness of the use of pedagogical technologies in the transmission of the national musical heritage from generation to generation through the improvement of technologies for the formation and development of national and classical musical hearing aids.

\section{KEYWORDS}

Pedagogical technology, musical talent, interactivity, pedagogical technology, modern education, method, creativity

\section{INTRODUCTION}

The primary purpose in an educational institution, whether it is a school, college, or a University, is to teach students. In addition to teaching, the teacher seeks the most convenient, effective ways of teaching and organizes the learning process in an 
interesting and meaningful way. Such activity itself can be called educational technology. It is necessary to make sure that this process is effective, along with the introduction of different ways and methods of pedagogical education in their activities in pedagogical technology or in a special set of teaching aids, methods and forms of educational technology

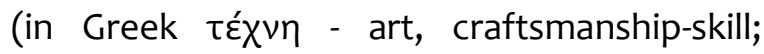
$\lambda$ ópos-word, education [1].

\section{MATERIALS AND METHODS}

The use of active teaching methods, such as conversation, "brainstorming", slide presentations, excerpts from educational films, music videos, audio recordings as well as the main features of pedagogical technologies in music education: conceptuality, systematisms, didactic goals, innovation, acceptability, correction, reproduction, management, efficiency by teachers, help to achieve high efficiency in the formation of musical trends in students $[2,3]$.

This interactive method of education forms tendencies of differentiation, analysis, classification of many types of national music along with serving to further enhance the physiological, psychological and mental abilities of students. Compared to traditional education: the teacher's activity gives way to the students' activity and the teacher's task is to create conditions for their initiative. The teacher rejects the role of a specific filter, through which it transmits educational information and acts as an assistant in working with information sources. Interactive learning implies a different essence of the educational process: not from theory to practice, but to its theoretical understanding through the formation of a new experience.
The experience and knowledge of the participants in the learning process serve as a source of their mutual learning and mutual enrichment [4]. This allows the learner to systematize multiple tendencies. As a result, while preventing blind adherence to different musical genres, the mutual classification of transformational trends affecting national classical music perception leads to the formation of their own views on their advantages, achievements and disadvantages over each other. The following are examples of such interactive methods:

Chain:

The worm line in which the play of the song is performed in turn, the method in which it is played alternately. It allows activating the attention of each singer, attracting the awareness of the next participant in a timely manner.

Small performances:

each participant performs solo or in an ensemble (duet, trio) as a soloist during the session. Thus, it helps to strengthen the personal qualities of the leader, to overcome the feelings of fear that may occur in front of the audience, albeit in small forms.

Quiz:

Conducted as a musical test, video questions or a musical battle of two teams.

Theater production: learning musical tales through many musical characters. Afterwards, performed in costumes, decorations, and appropriate musical design (phonogram or instrumental song). Examples of musical tales: 
"Zumrad and Qimmat”, “Egrivoy and To'g'rivoy”.

Educational expedition: group visits to theaters, music concerts and museums. Subsequent analysis of classroom impressions, making conclusions.

Mass execution: the result of active work in the classroom - performance at events, concerts and competitions. Adaptation to concert conditions: stage space, sound quality, and psychological pressure from the audience.

Creative task: Any holiday does not go by without leaving a mark on children's community. Obviously, each student tries to show their unique characteristics, share their suggestions in the preparation process to arrange the thematic event, the design of the music hall, and so on [5].

The main results of the education are teacher - student - teacher cooperation, the ability of developing creative activity faculty, tolerance for the opinions of others, communication, compromise and finding in the the formation of national and classical music listening skills in students and formation of transformational trends affecting musical perception today. The main goal of the interactive methodology is to develop the ability to learn independently through interaction. At the same time, it is vital to pay attention to students' interactions with each other. Indeed, such trends play an important role in the expansion and development of musical views, musical thinking in young people through interaction.

The main methodological principles of interactive education for students are:
- Careful selection of work materials and teaching methods;

- Comprehensive analysis of specific practical examples of musical activity, the use of comparative and auditory analysis;

- Ensuring continuous visual communication with all students;

- Active use of technical means, including handouts and didactic materials in the form of tables, slides, educational films, videos, video clips, video equipment, and describing studied problem with their help;

- Continuous support of the teacher's interaction within the active group, quick intervention of the teacher in the discussion in case of unexpected difficulties.

Important situations and circumstances in determining the process of pedagogical training for pedagogical technology: predetermining the tasks that the pupil or student will face in the process of learning, defining the content of education at each stage of teaching (curriculum, syllabus, subject matter, availability of teaching aids), knowledge and concepts, their level of complexity and scope and determining whether they are accordant to the degree of conformity of the student's knowledge and skills, preparing forms and means of education (additional resources, question and answer, discussion, test questions, visual aids, hearing aids using technical means, listening sources); planning of in-class and out-of-class assignments for students to objectively assess the knowledge and skills acquired by them in accordance with the criteria for assessing the 
quality of learning outcomes and the level of mastery are all considered as the tasks of pedagogical technologies.

When using pedagogical technologies in the formation of national music listening skills of students, it is necessary to pay attention to the following in the preparation of future teachers for pedagogical activities in pedagogical universities:

1. Studying new and effective work experience of teachers working on the basis of technological approach;

2. Increasing the technological approach activity of pedagogues, hence, identifying the causes of problems that hinder it, looking for more effective ways to work on the basis of the technological approach;

3. Studying the lessons of experienced teachers in order to identify and apply their unique methods of application of advanced pedagogical technologies, their differences and similarities, shortcomings and achievements.

In addition, today's pedagogue in the process of musical transformation trends should pay special attention to the followings in the formation of national music listening skills of students and the use of pedagogical technologies:

\section{Modern approaches and innovations in the teaching of music culture.}

Organization of music culture lessons on the basis of modern requirements. Innovations in the teaching of music culture. Giving insight about innovations. Exploring the possibilities of applying innovations in the teaching of music culture. Organization of music culture lessons on the basis of modern requirements.

\section{Foreign advanced practices in teaching music culture.}

The content of music science in developed countries, progressive practices in its teaching and technological methods of their use.

\section{Methods of integration in the organization of music culture lessons.}

The integral connection of the science of music culture with other disciplines. Examples of the connection between music and the fine arts, history, literature, geography, physical education, nature, physics, computer science, mathematics, and other general sciences. Activities aimed at the formation of competencies and the orientation of students to the profession by linking the subject of music culture with other disciplines during lessons.

\section{The use of modern information technology programs in the lessons of music culture.}

Didactic tools, teaching aids and resources prepared using computer applications. Use of e-learning literature, teaching systems, multimedia and other software in the classroom. Working with Power Point, Sibelius, Audacity programs in music culture lessons and their effective use.

The second version of the e-program "Innovative Approach to Music Education" by E.Tadjibaev, a doctoral student at Namangan State University, A.Sultanov, an independent 
researcher at Fergana State University, and I.Kirgizov, can be seen as an example of this.

\section{Observation and analysis of music culture lessons.}

Preparing to organize music culture classes. Lesson analysis based on open, demonstration, sample, reporting lessons and their requirements. Observation, analysis, discussion and evaluation of open lessons on music culture.

With the above in mind, we will not only preserve our national music, but also contribute to its further enhancement for future generations by teaching students examples of our national musical heritage. In this regard, a number of measures taken by our state also serve as a basis for the above opinion.

In particular, the Resolution "on Approval of the Concept of Further Development of National Culture in the Republic of Uzbekistan" No PP-4038 of the President of the Republic of Uzbekistan dated November 28, 2018 provides:

preserving our national musical heritage passed down from generation to generation by improving the technology of formation and development of national and classical music listening skills in students, developing our musical heritage in new conditions and to create ample opportunities for our people to enjoy; supporting the activities of composers and musicians, holding competitions at various levels to identify talented performers among amateurs, further development of the tradition of teacher-student in order to advance traditional music genres in new conditions. In this resolution, adopted by our state, the further development of national culture and art is considered as an integral and essential part of the socio-economic development of the country.

\section{CONCLUSION}

The Concept is implemented in accordance with the requirements of the Action Strategy for the five priority areas of development of the Republic of Uzbekistan for 2017-2021, in line with national and international advanced practices, and socio-political changes in our country. Recognizing that in the process of historical development of the country, culture and art have preserved and accumulated the spiritual wealth of our people, instilled a sense of solidarity, patriotism and national pride in our people, emphasizing the priority of culture, ensuring a higher quality of life, achieving the unity of citizens in it, the formation of spiritual, responsible, independent-minded creative youth are also the content of the reslution.

\section{REFERENCES}

1. Abdurauf Fitrat "Uzbek classic music and its history”, Tashkent: 1993

2. Golom Zafariy "The delicacy of Uzbek music", 1992

3. T.Ortikov "Methodology of teaching music", Tashkent: “Muharrir” 2000

4. Urazova M.B., Eshpulatov Sh.N., A future music director's planning activities. // Methodical manual. - T.: TSPU Rhizograph, 2014. 
The American Journal of Social Science and Education Innovations (ISSN - 2689-100x)

Published: May 30, 2021 | Pages: 145-149

Doi : https://doi.org/10.37547/tajssei/Volume03Issue05-26

2021: 5.857

OCLC - 1121105668

5. Ishmuhamedov R., Yuldashev M. -

Innovative pedagogical technologies

in education. - T.: Nihol, 2013. 